\title{
Alelopatic Effects of Tectona grandis L.F. in the Germination and Initial Development of Lettuce (Lactuca sativa L.)
}

\author{
Márcia Cunegundes da Silva ${ }^{1}$, Emmanoella Costa Guaraná Araujo ${ }^{1}$, Thiago Cardoso Silva ${ }^{1}$, \\ Adão Batista de Araújo ${ }^{1}$, Tarcila Rosa da Silva Lins ${ }^{1}$, Shyrlaine Lilian Moura Leão ${ }^{1} \&$ Tarcísio Viana de Lima ${ }^{1}$ \\ ${ }^{1}$ Federal Rural University of Pernambuco, Recife, Brazil \\ Correspondence: Emmanoella Costra Guaraná Araujo, Federal Rural University of Pernambuco, Recife, Brazil. \\ E-mail: manuguarana@gmail.com
}

Received: September 30, 2018

Accepted: November 2, $2018 \quad$ Online Published: December 15, 2018

doi:10.5539/jas.v11n1p382

URL: https://doi.org/10.5539/jas.v11n1p382

\begin{abstract}
This study aimed to evaluate the allelopathic effects of aqueous extracts of Tectona grandis L.F. in various concentrations produced from leaves and flowers. Seeds of lettuce (Lactuca sativa L.) and germitest paper as substrate were used, the germitest paper was moistened with distilled water, and aqueous extract in concentrations of $100 \%, 75 \%, 50 \%, 25 \%$ and $0 \%$ (distilled water). The extracts were homogeneously deposited on twenty-five seeds evenly distributed in gerbox-type boxes. The materials used in the experiment were previously sterilized with alcohol $(70 \%)$. A completely randomized experimental design with four replicates was used and the experiment was conducted under natural conditions of temperature and humidity. The tests were carried out in the laboratory, the experiment was watched for 10 days always at the same hour and the variables analyzed were Germination Percentage $(\% \mathrm{G})$, Speed of Germination Index (SGI), Mean germination time (MGT) and Mean speed of germination (MSG). The data were submitted to Analysis of Variance and compared by Tukey test considering $95 \%$ of probability. It was observed that there were no significant differences in leaf and flower extracts for the variables \%G, MGT and MSG, however, in SGI aqueous leaf extract differed significantly at the highest concentrations ( $75 \%$ and $100 \%)$. It was concluded that aqueous extracts of leaves and flowers of $T$. grandis had no inhibitory potential in relation to the percentage and average germination time of lettuce seeds at any of the concentrations.
\end{abstract}

Keywords: teak, allelopathy, germination test

\section{Introduction}

An alternative ecologically viable production is the combined cultivation of species, integrating annual crops with forestry species. In addition to increasing biological diversity, it raises the economic viability of the system, which provides a range of financial return options for those who produce. However, it is necessary to know the synergistic and antagonistic effects that individuals can exert on others to maximize the production.

Allelopathy is an example of an effect caused by plants that share the same space, which may have direct or indirect implications, which may be beneficial or not. The effects of this mechanism are caused by compounds produced in the secondary metabolism of the organisms, which may interfere with the germination and development of some nearby plants (Soares, 2000; Goldfarb et al., 2009; Taiz et al., 2017).

In general, allelopathic effects can be confused with competition. However, they are substances that inhibit or hinder some physiological functions of the near individuals, while competition is characterized by the dispute for the element's indispensable for their survival (water, light, nutrients). Thus, studies on the allelochemical effects are relevant for agriculture, increasing the efficiency of the use of the soil, favor the production of biological herbicides, benefit the interactive processes between the living beings, among others (Veronese, 2013).

According to Albuquerque et al. (2011), the allelochemical are substances emitted directly by the organs of the plants and by the decomposition of litter into the soil.

The greater or less resistance to the allelochemicals changes according to the characteristics of the plants to neutralize these substances. The production of these secondary metabolites by the emitting plants is influenced by climatic conditions, such as: electromagnetic intensity, temperature, water supply, nutrient availability, soil texture and microorganism action (Guimarães, 1999; Santos, 2008). 
Pires and Oliveira (2011) indicate that one of the efficient ways of testing the allelopathic effects of one species over another is doing a germination test, because of its simplicity, and rapid achievement of results. Studies on allelopathic potential of the teak (Tectona grandis L.F.) species are few, so it is necessary to know about the allelopathic effects of the species.

Teak has been cultivated since the 18th century, with the aim of reducing deforestation of native forests due to illegal logging by the British for shipbuilding. Its planting began in some countries of tropical Asia and expanded to tropical areas, including Brazil, where plantations beyond short-cycle and high-density plantations than those practiced in Southeast Asia (Figueiredo et al., 2005). Thus, teak commercial plantations in Brazil adapted well to the conditions as a form of positive investment, being the species used in consortia.

One of the ways of evaluating the allelopathic potential of a species is through tests using species sensitive to the process of allelopathy. Therefore, the use of lettuce seed is indicated in these studies because it presents a high degree of sensitivity for rapid and uniform germination test and that allows to obtain answers of the results even with minimum concentrations of allelochemicals (Souza \& Furtado, 2002)

This study aimed to evaluate the allelopathic effects of aqueous extracts of T. grandis L.F. in various concentrations produced from leaves and flowers.

\section{Method}

The vegetal parts of teak used in the preparation of the extracts were collected from two adult teak specimens at the Campus of the Federal Rural University of Pernambuco, located in the city of Recife/PE-Brazil $\left(08^{\circ} 03^{\prime} 14^{\prime \prime}\right.$ S; $34^{\circ} 52^{\prime} 52^{\prime \prime} \mathrm{W}$ ), observing good phytosanitary characteristics of the individuals.

All the material used in this experiment was previously washed with water and neutral detergent, then sterilized with alcohol (70\%).

Aqueous extracts of $250 \mathrm{~g}$ of fresh samples were produced in $1 \mathrm{~L}$ of distilled water, comminuted in a blender and filtered on a cloth strainer just after crushed, being this extract $100 \%$ concentrated. From that, dilutions were made the $75 \%, 50 \%$ and $25 \%$ extracts with distilled water, and the distilled water $(0 \%)$ as the control. These steps were followed for both leaf and flower samples.

The germitest paper was the substrate used, it was previously sterilized in a forced aeration oven at $103 \pm 2{ }^{\circ} \mathrm{C}$, for two hours according to the Rules for Seed Analysis-RAS (MARA, 2009). Subsequently, the germitest papers were packed in gerbox boxes $(20 \times 12 \times 10 \mathrm{~cm})$ corresponding to a sample unit, which was moistened with distilled water in the proportion of $3 \times$ the weight of the paper, being accommodated the seeds after dampening, and the extracts were then added.

The seeds were distributed on the substrate, being organized in five rows with five units each. According to the RAS (MARA, 2009), seed spacing should be uniform and sufficient to avoid competition and contamination between seeds. Therefore, each sample unit had 25 seeds.

Then, $2.5 \mathrm{~mL}$ of the extracts were added over all seeds of the experimental unit using a pipette so that the solution was homogeneously distributed, not needing to moisten again.

The experimental design was completely randomized, with five replications and five treatments for each part of the plant studied. The primary root protrusion of $5 \mathrm{~mm}$ was considered as the germination identification criterion, and for the emergence, growth of $1 \mathrm{~cm}$ of the coleoptile above the substrate. Germination of lettuce seeds was evaluated daily for 10 days, always at the same time. The experiment was carried out in the laboratory under natural hydrothermal conditions $\left(25^{\circ} \mathrm{C}\right.$ and $72 \%$ UR).

The variables analyzeds were:

(a) Germination Percentage $(\% \mathrm{G})$, based on the daily count of germinated seeds, based on the principle that the sample units with the highest percentage of normal seedlings will be the most vigorous, using equation:

$$
\% \mathrm{G}=\frac{\mathrm{NG}}{\mathrm{NT}} \times 100
$$

Where,

$\mathrm{NG}=$ number of germinated seeds; $\mathrm{NT}=$ total number of seeds per treatment.

(b) Speed of Germination Index (SGI), obtained by calculation based on the daily count of the number of seeds that generate normal seedlings in a period of seven days. To obtain the data for later calculation, normal 
seedlings were counted daily, at the same hour, since the first normal seedlings appeared. The equation postulated by Maguire (1962):

$$
\mathrm{SGI}=\frac{\mathrm{G} 1}{\mathrm{~N} 1}+\frac{\mathrm{G} 2}{\mathrm{~N} 2}+\ldots+\frac{\mathrm{Gx}}{\mathrm{Nx}}
$$

Where,

$\mathrm{G} 1, \mathrm{G} 2, \ldots \mathrm{Gx}=$ number of daily germinated seeds; $\mathrm{N} 1, \mathrm{~N} 2, \ldots \mathrm{Nx}=$ number of count days.

(c) Mean germination time (MGT), corresponding to the time necessary for the germination of a seed group, in which the faster these germinations occur, the more vigorous the observed seeds:

$$
\mathrm{MGT}=\sum_{\mathrm{i}=1}^{\mathrm{k}} \mathrm{ni} \cdot \mathrm{ti}+\sum_{\mathrm{i}=1}^{\mathrm{k}} \mathrm{ni}
$$

Where,

$\mathrm{ni}=$ number of seeds germinated in a certain time interval ti.

(d) Mean speed of germination (MSG), to quantify germination from the kinetic point of view. The lower the value the more vigorous the seed lot will be, corresponding to the inverse of the average time:

$$
\mathrm{MSG}=\frac{1}{\mathrm{MGT}}
$$

Statistical analyzes were carried out by transforming the data obtained using $\operatorname{arcsen} \sqrt{(\mathrm{x} / 100)}$, submitted to ANOVA and compared by the Tukey's test at $5 \%$ of probability using the RBIO software, and applaying regression analysis if necessary.

\section{Results}

The different concentrations of aqueous extracts made with teak leaves did not significantly affect percentage, the mean time nor the speed of germination. However, it was verified that the germination rate index of the treatments $75 \%$ and $100 \%$ differed statistically from the control treatment, according to the results presented in Table 1.

Table 1. Percentage of germination (\%G), Speed of Germination Index (SGI), Mean germination time (MGT, in days) and Mean speed of germination (MSG, in days ${ }^{-1}$ ) of germination of lettuce seeds (Lactuca sativa L.) submitted to different concentrations of aqueous leaf extract of Tectona grandis L. F.

\begin{tabular}{lllll}
\hline Concentration of the extract (\%) & Germination (\%) & SGI & MGT (days) & ${\text { MSG }\left(\text { days }^{-1}\right)}^{\text {Controle }}$ \\
\hline 5 & $96.80 \mathrm{a}$ & $10.73 \mathrm{a}$ & $5.56 \mathrm{a}$ & $0.18 \mathrm{a}$ \\
50 & $92.80 \mathrm{a}$ & $9.92 \mathrm{ab}$ & $6.34 \mathrm{a}$ & $0.16 \mathrm{a}$ \\
75 & $90.40 \mathrm{a}$ & $9.33 \mathrm{abc}$ & $8.56 \mathrm{a}$ & $0.13 \mathrm{a}$ \\
100 & $93.60 \mathrm{a}$ & $8.40 \mathrm{bc}$ & $9.04 \mathrm{a}$ & $0.13 \mathrm{a}$ \\
CV $(\%)$ & $88.00 \mathrm{a}$ & $7.70 \mathrm{c}$ & $10.38 \mathrm{a}$ & $0.13 \mathrm{a}$ \\
$*$ d.m.s. & 5.97 & 11.75 & 52.54 & 29.20 \\
\hline
\end{tabular}

Note. Averages followed by equal letters in the columns do not differ significantly from each other by the Tukey's test at the $5 \%$ probability level. *d.m.s. (significant average difference).

No significant differences were observed for the evaluation of the allelopathic potential of the aqueous leaf extracts as a function of the percentage of germination, SGI and mean germination time. However, the concentrations of the $25 \%$ and $100 \%$ teak flower's extracts were statistically diverged in relation to the mean germination speed. The results are presented in Table 2. 
Table 2. Percentage of germination $(\% \mathrm{G})$, Speed of Germination Index (SGI), Mean germination time (MGT, in days) and Mean speed of germination (MSG, in days ${ }^{-1}$ ) of germination of lettuce seeds (Lactuca sativa L.) submitted to different concentrations of aqueous flower extract of Tectona grandis L. F.

\begin{tabular}{lllll}
\hline Concentration of the extract (\%) & Germination (\%) & SGI & MGT (days) & MSG (days $\left.^{-1}\right)$ \\
\hline 0 & $96.80 \mathrm{a}$ & $10.73 \mathrm{a}$ & $5.56 \mathrm{a}$ & $0.18 \mathrm{ab}$ \\
25 & $93.60 \mathrm{a}$ & $12.75 \mathrm{a}$ & $5.02 \mathrm{a}$ & $0.21 \mathrm{a}$ \\
50 & $92.80 \mathrm{a}$ & $9.78 \mathrm{a}$ & $8.96 \mathrm{a}$ & $0.15 \mathrm{ab}$ \\
75 & $92.80 \mathrm{a}$ & $8.65 \mathrm{a}$ & $10.16 \mathrm{a}$ & $0.13 \mathrm{ab}$ \\
100 & $96.80 \mathrm{a}$ & $9.04 \mathrm{a}$ & $13.28 \mathrm{a}$ & $0.10 \mathrm{~b}$ \\
\hline CV $(\%)$ & 5.04 & 22.23 & 1.69 & 34.59 \\
*d.m.s. & 9.03826 & 4.29 & 10.05 & 0.1 \\
\hline
\end{tabular}

Note. Averages followed by equal letters in the columns do not differ significantly from each other by the Tukey's test at the $5 \%$ probability level. *d.m.s. (significant average difference)

Figure 1 shows the regression graphs in relation to the concentration of the extracts and the effects of the parts of the plant.
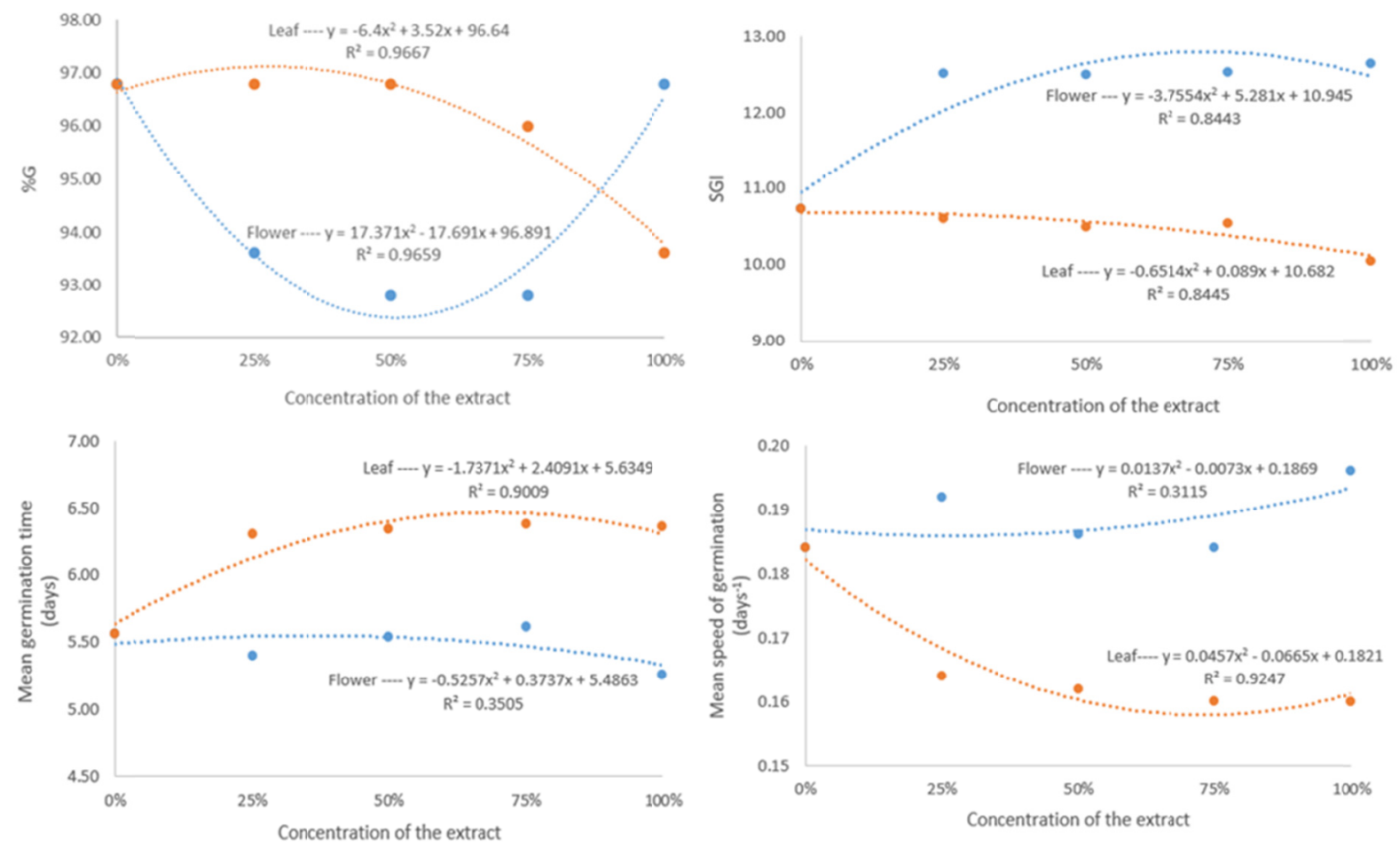

Figure 1. Regression graphs of percentage of germination $(\% \mathrm{G})$, Speed of Germination Index (SGI), Mean germination time (MGT, in days) and Mean speed of germination (MSG, in days ${ }^{-1}$ ) of germination of lettuce seeds (Lactuca sativa L.) submitted to different concentrations of aqueous of flower and leaf extract of Tectona grandis L. F.

\section{Discussion}

According to the results obtained in relation to the leaves, the extracts interfered only in the SGI. In relation to the flowers, only the mean speed of germination of the lettuce seeds were influenced by the extracts. For the other parameters, the two parts of teak did not cause significant interference, showing that this material has little influence on the germination of lettuce seeds.

No other studies evaluating allelopathic potential of teak were found in the literature. 
Viecelli and Cruz-Silva (2009) found that different dosages of aqueous extract of Salvia officinalis L. leaves, interfered significantly in the variable SGI and the initial development of lettuce seedlings submitted to the high concentrations of the extract. Silva et al. (2015) analyzing extracts of leaves of the species of the Lamiaceae's family, verified that aqueous extracts made from Mentha $s p$. L. leaves, Rosmarinus officinalis L, Origanum majorana L. and S. officinalis, reduced the germination of lettuce seeds; aqueous extracts made from Coleus barbatus (Andrews) B. stimulated their germination of lettuce seeds. These results differ from the present study.

Rosado et al. (2009) studying leaf extracts with different concentrations of Ocimum basilicum L., of the Lamiaceae's family, observed that the species had no influence on the percentage of germination of lettuce seeds (L. sativa L.), but also for species Melissa officinalis L. and Lycopersicon esculentum Mill. For the variable SGI, it presented significant differences for $L$. esculentum seeds.

In a study using extracts of different concentrations of Sesbania virgata leaves, Araujo, Silva and Lima (2018) observed that there was no significant difference between the treatments in relation to the percentage of lettuce germination when compared to the control. Also based on the same study, the variable SGI showed a significant difference in the concentrations $50 \%, 75 \%$ and $100 \%$; in the variable increase of the average time, the presence of the extracts increased the period for emergence of the plants and the average speed suffered a significant reduction on the interference of the extracts; and in relation to the average time the presence of the extracts increased the period for emergence of the plants and consequently the average speed decreased.

Towards results over flower extracts, Andrade (2003) observed, in studies based in based on aqueous extracts made from Acacia podalyriaefolia flowers (Mimosa's family), the presence of allelopathic effects in tests of germination of lettuce seeds. Oliveira et al. (2012) verified working with extracts from Erythrina velutina flowers that there was no interference in the variable $\% \mathrm{G}$, but SGI differed significantly from the control treatment.

Oliveira et al. (2005) analyzing aqueous extracts of flowers of Chloroleucon tortum (Mart.) Pittier observed total inhibition of lettuce germination, which clearly shows the presence of allelochemical substances in the plant material.

Besides that, De Conti and Franco (2011) observed in a study with flower extracts Casearia sylvestris Sw that there was inhibition in the germination and in the growth of seeds of lettuce; in relation to the SGI the C. sylvestris flower extracts showed a delay in the germination process from the concentration of $25 \%$, where that variable presented a reduction of values with the increase of the concentrations of the extracts used, which corroborated with this study.

\section{Conclusions}

Aqueous extracts of teak leaves and flowers from Tectona grandis had no inhibitory potential in relation to the percentage and mean germination time of lettuce seeds at any of the concentrations.

Leaf extracts interfered in the SGI, but not in relation to the speed of germination. The leaves extracts had an inverse behavior, interfering in the germination speed and not causing changes in the SGI in relation to the different concentrations of extract.

Thus, it was possible to verify that there were no significant difference treatments, but they exert influence on the germinative behavior of lettuce seeds, especially in the highest concentrations, occurring mainly in the rate of germination speed of teak leaves. It is worth mentioning that, due to the scarce work in the allelopathy field with teak, these results may contribute to other researches in this segment.

\section{References}

Albuquerque, M. R. C., Santos, P. A., Melo Filho, R. J. M. C., Nogueira, C. A. G., Câmara, A., \& Ramos, R. (2011). Allelopathy, an alternative tool to improve cropping systems: A review. Agronomy for Sustainnable Development, 31(2), 379-395. https://doi.org/10.1051/agro/2010031

Andrade, C. A., Miguel, M. D., Miguel, O. G., Ferronato, M. L., Peitz, C., Cunico, M., ... Kerber, V. A. (2003). Efeitos alelopáticos das flores da Acacia podalyriaefolia A. Cunn. Visão Acadêmica, 4(2), 93-98. https://doi.org/10.5380/acd.v4i2.528

Araujo, E. C. G., Silva, T. C., \& Lima, T. V. (2018). Efeitos Alelopáticos de Sesbania virgata (Cav.) Pers na germinação de sementes de Alface. Revista Engenharia na Agricultura, 26(2), 101-109. https://doi.org/ 10.13083/reveng.v26i2.862

De Conti, D., \& Franco, E. T. (2011). Efeito alelopático de extratos aquosos de Casearia sylvestris Sw. na germinação e no crescimento de Lactuca sativa L. Revista Brasileira de Agrociência, 17(2-4), 193-203. 
Figueiredo, E. O., Oliviera, L. C., \& Barbosa, L. K. F. (2005). Teca (Tectona grandis L.F.): Principais perguntas do futuro empreendedor florestal (Documentos, 97). Rio Branco: EMBRAPA Acre.

Goldfarb, M., Pimentel, L. W., \& Pime, N. W. (2009). Alelopatia: Relações no agroecossistemas. Revista Tecnologia e Ciência Agropecuária, 3(1), 23-28.

Guimarães, R. M. (1999). Fisiologia de sementes. Lavras: UFLA.

Maguire, J. D. (1962). Speed of germination-aid in selection and evaluation of seedling emergence and vigor. Crop Science, 2(1), 176-177. https://doi.org/10.2135/cropsci1962.0011183X000200020033x

MARA (Ministério da Agricultura e Reforma Agrária). (2009). Regras para análise de sementes. Brasília: Coordenação de Laboratório Vegetal, Departamento de Defesa Vegetal.

Oliveira, A. K., Coelho, M. F. B., Maia, S. S. S., Diógenes, F. E. P., \& Medeiros Filho, S. (2012). Alelopatia de extratos de diferentes órgãos de mulungu na germinação de alface. Horticultura Brasileira, 30(3), 480-483. https://doi.org/10.1590/S0102-05362012000300020

Oliveira, M. N. S., Mercadante-Simões, M. O., Ribeiro, L. M., Lopes, P. S. N., Gusmão, E., \& Dias, B. A. S. (2005). Efeitos alelopáticos de seis espécies arbóreas da família Fabaceae. Montes Claros, 7(2).

Pires, H. H., \& Oliveira, V. R. (2011). Alelopatia. In R. S. Oliveira Jr., N. J. Constantin, \& M. H. Inoue (Eds.), Biologia e manejo de plantas daninhas. Curitiba: Omnipax.

Rosado, L. D. S., Rodrigues, H. C. A., Pinto, J. E. B. P., Custódio, T. N., Pinto, L. B. B., \& Bertolucci, S. K. V. (2009). Alelopatia do extrato aquoso e do óleo essencial de folhas do manjericão "Maria Bonita" na germinação de alface, tomate e melissa. Revista Brasileira de Plantas Medicinais, 11(4), 422-428. https://doi.org/10.1590/S1516-05722009000400010

Santos, F. C. D., Novais, R. F., Neves, J. C. L., Foloni, J. M., Albuquerque Filho, M. R., \& Ker, J. C. (2008). Produtividade e aspectos nutricionais de plantas de soja cultivadas em solos de cerrado com diferentes texturas. Revista Brasileira de Ciência do Solo, 32, 2015-2025. https://doi.org/10.1590/S0100-0683 2008000500023

Silva, L. R., Cruz-Silva, C. T. A., Barros, N. A. T., \& Olivetti, M. M. C. (2015). Alelopatia de espécies da família Lamiaceae sobre o desenvolvimento de alface. Cultivando o Saber, 8(1), 59-73.

Soares, G. L. G. (2000). Inibição da germinação e do crescimento radicular de alface (cv. Grand Rapids) por extratos aquosos de cinco espécies de Gleicheniaceae. Floresta e Ambiente, 7, 190-197.

Souza, I. F., \& Furtado, D. A. S. (2002). Caracterização de aleloquimicos do centeio (Secale cereale) e seu potencial alelopático sobre plantas de alface (Lactuca sativa). Ciência e Agrotecnologia, 26(5), 1097-1099.

Taiz, L., Zeiger, E., Moller, I. M., \& Murphy, A. (2017). Fisiologia e desenvolvimento vegetal (6th ed.). Porto Alegre: Artmed.

Veronesi, M. B. (2013). Avaliação da tolerância de duas espécies nativas às fitotoxinas exsudadas por Sesbania virgata (Cav.) Pers. Dissertação (Mestrado em Biodiversidade Vegetal e Meio Ambiente). São Paulo: Instituto de Botânica da Secretaria de Estado do Meio Ambiente.

Viecelli, C. A., \& Cruz-Silva, C. T. A. (2009). Efeito da variação sazonal no potencial alelopático de sálvia. Semina: Ciências Agrárias, 30(1), 39-46. https://doi.org/10.5433/1679-0359.2009v30n1p39

\section{Copyrights}

Copyright for this article is retained by the author(s), with first publication rights granted to the journal.

This is an open-access article distributed under the terms and conditions of the Creative Commons Attribution license (http://creativecommons.org/licenses/by/4.0/). 